\title{
In vitro Evaluation of ITKs (Indigenous Technical Knowledge's) Techniques viz Application of Panchgavya and Plant Extracts against Rhizoctonia solani
}

\author{
N.K. Toorray ${ }^{1 *}$, P.K. Tiwari ${ }^{2}$, A.S. Kotasthane ${ }^{3}$ and R.R. Saxena ${ }^{2}$ \\ ${ }^{1}$ CARS, Marra, Patan (Durg), IGKV, Chhattisgarh, India \\ ${ }^{2}$ CoA, IGKV, Raipur, Chhattisgarh, India \\ ${ }^{3}$ Department of Plant Pathology, CoA, IGKV, Raipur, Chhattisgarh, India \\ *Corresponding author
}

\section{A B S T R A C T}

\section{Keywords}

ITKs, Panchgavya, Leaf extracts, Rhizoctonia solani, Sheath blight, in vitro, Management

Article Info

Accepted:

17 October 2019 Available Online:

10 November 2019
The development of need based cost effective plant protection measures for effective management of rice diseases is the need of the future for higher and sustainable rice yield. Since, the existing chemical control measures being costly and may favour development of resistance in pathogens, the potential alternative methods have been explored in the present studies. An experiment was conducted to evaluate the effect of plant extracts and panchgavya in vitro against Rhizotonia solani causing sheath blight of paddy. Among the plant extracts, Maximum mycelial growth reduction was recorded in Garlic extract (80.51\%) followed by Neem extract (59.77\%), Dhatura extract (40.22) and Panchgavya (18.59) in cold water. Maximum reduction in mycelial growth was recorded in Garlic extract $(75.18 \%)$ followed by Datura $(45.92 \%)$ and Neem $(41.70 \%)$ over control in hot water. Mycelial growth reduction was recorded maximum in Datura extract (63.99\%) followed by Garlic extract (58.74\%) and Neem extract (47.92\%) in Acetone chemical. The plant extracts and pachgavya found effective in vitro against $R$. solani causing sheath blight of paddy during kharif season 2016-2017. Plant leaf extracts and Panchgavya taken in the study showed significant reduction in mycelial growth over control. Among all the treatments Garlic extract, Neem extract and Dhatura extract were found effective against Rhizoctonia solani in vitro whereas, Lemmon grass extract and Panchgavya were found less effective as comparision to Garlic extract, Neem extract and Dhatura extract.

\section{Introduction}

Rice (Oryzae sativa L.) is the staple food crop of over half of the world's population. Losses due to pests and diseases are one of the major constraints in rice production. Sheath blight disease of rice cause considerable loss, especially, in areas where high yielding varieties are grown. Rhizoctonia solani which causes rice sheath blight is both soil and water borne and management of the disease is difficult (Kagale et al., 2004). Sheath blight is one of the common and destructive diseases of rice in India. The disease is characterized by 
the formation of lesions on leaf sheaths and culms at the water level, which become confluent giving characteristic banded appearance. The infection may spread up to the culms, killing all the leaves under favourable weather conditions. Losses up to 20 per cent in grain yield have been reported when disease invades at flag leaf stage.

There are several important reports the management of this disease by medicinal plants and Panchgavya. The losses due to sheath blight can be managed through the foliar application of plant extracts and Panchgavya in disease management is considered as eco-friendly, without any environmental pollution. The present study was carried out to explore, the efficiency of some plant extracts and Panchgavya against sheath blight of paddy caused by Rhizoctonia solani in vitro.

\section{Materials and Methods}

In vitro, Panchgavya and leaf extract of different plants were evaluated for their antifungal activity against Rhizoctonia solani. The fresh leaves of four plants namely, Neem (Azadirachta indica), Garlic (Allium sativum), Datura (Datura stramonium), Lemon grass (Cymbopogan flexousus), were collected. The extract of each plant species was prepared in cold water, hot water and Acetone by leaf tissues and solvent in 1:1 ratio (w/v).

The unique combination in appropriate quantity of five products of cow i.e. milk, curd, ghee, urine and fresh dung were used in the panchgavya. The cow milk, curd and urine contains microorganisms, which are useful in many ways. Poisoned food technique (Sumangala and Patil, 2009) was employed to know the effect of panchgavya against $R$. solani. $10 \%$ concentration of panchgavya was prepared with sterilized water and thoroughly mixed in melted Potato Dextros Agar Medium.

\section{Cold water}

Plant leaves were thoroughly washed with distilled water and crushed in 1:1 ratio of distilled water in a pastle and mortar individually. Extract was passed through a double layer muslin cloth and then through Whatman's filter paper No.1. This filtrate was considered as stock solution.

\section{Hot water}

The extract of each plant species was prepared by taking leaf tissues and distilled water in 1:1 ratio $(\mathrm{w} / \mathrm{v})$, boiled for 30 minutes in water bath and extracted material was filtered through double layer muslin cloth and filtrate was then passed through Whatman's filter paper No.1. This filtrate was considered as stock solution.

\section{Chemical}

Fresh leaves of plant species were washed thoroughly with distilled water and crushed in pastle and mortar with Acetone individually in 1:1 ratio $(\mathrm{w} / \mathrm{v})$. Extract was passed through a double layer muslin cloth and then through Whatman's filter paper No.1. This filtrate was considered as stock solution.

The extracts were mixed aseptically in molten PDA to have final dilutions of $10 \%$ and then poured in sterilized petri plates. Sterile distilled water mixed in same dilutions in PDA served as control. Each petri plate was inoculated with 48-72 hrs old sclerotia of Rhizoctonia solani and three replications were maintained. The inoculated plates were incubated at $28^{\circ} \mathrm{C} \pm 2^{\circ} \mathrm{C}$. The mycelial growth and sclerotial formation were recorded seven days after incubation. The percent inhibition of mycelia growth was calculated as per the 
following formula described by Vincent (1947).

Inhibition $(\%)=\mathrm{C}-\mathrm{T} / \mathrm{C} \times 100$

Where

$\mathrm{C}=$ Diameter of fungus colony $(\mathrm{mm})$ in control plate,

$\mathrm{T}=$ Diameter of fungus colony $(\mathrm{mm})$ in treated plate.

\section{Results and Discussion}

\section{In vitro condition}

Four plant leaf extracts and Panchgavya were tested under in vitro condition against $R$. solani at $10 \%$ concentration. Observations for mycelial growth and sclerotial formation were recorded and presented in table 1 .

Four medicinal plant leaf extracts were tested under in vitro condition against $R$. solani at $10 \%$ concentration. Observations for mycelial growth and sclerotial formation were recorded and presented in table 1. Medicinal plant leaf extracts taken in the study showed significant reduction in mycelial growth over control. The mycelial growth reduction ranged from 0 to $80.51,19.92$ to 75.18 and 5.70 to 63.99 per cent in cold water, hot water and Acetone extracts, respectively. The sclerotial formation was not recorded in all the medicinal plant leaf extracts tested.

\section{Cold water}

Minimum mycelial growth of $R$. solani was observed in Garlic $(17.53 \mathrm{~mm})$ followed by Neem $(36.20 \mathrm{~mm})$ Dhatura $(53.80 \mathrm{~mm})$ and Panchgavya $(73.27 \mathrm{~mm})$. These medicinal plant leaf extracts showed non-significant differences with each other. Mycelial growth was recorded maximum in Lemon grass (90.00mm). Dhatura leaf extract showed nonsignificant difference with Neem, Garlic and Lemon grass extract. Maximum mycelial growth reduction was recorded in Garlic extract $(80.51 \%)$ followed by Neem extract $(59.77 \%)$ over control.

\section{Hot water}

The minimum mycelial growth was observed in Garlic extract $(22.33 \mathrm{~mm})$ followed by Datura $(48.67 \mathrm{~mm})$ Neem $(52.47 \mathrm{~mm})$ and Panchgavya $(62.66 \mathrm{~mm})$. These medicinal plant leaf extracts showed non-significant differences with each other. Maximum mycelial growth was recorded in Lemon grass $(72.07 \mathrm{~mm})$ followed by Panchgavya $(62.66 \mathrm{~mm})$. The Neem leaf extract was statistically at par with Datura and Garlic leaf extract and but Lemon grass extract was statistically significant with all other extracts.

Maximum reduction in mycelial growth was recorded in Garlic extract (75.18\%) followed by Datura (45.92\%) and Neem (41.70\%) over control.

\section{Acetone}

Mycelial growth was minimum in Datura extract $(32.40 \mathrm{~mm})$ followed by Garlic $(37.13 \mathrm{~mm})$, Neem $(46.86 \mathrm{~mm})$, Panchgavya $(58.40 \mathrm{~mm})$ and Lemon grass $(84.87 \mathrm{~mm})$. All these medicinal leaf extracts showed nonsignificant differences with each other. Mycelial growth reduction was recorded maximum in Datura extract $(63.99 \%)$ followed by Garlic (58.74\%) and Neem (47.92\%) over control. Similar finding of leaf extracts and panchgavya also recorded by Sumangala and Patil (2009) that Panchgavya resulted in $86.30 \%$ inhibition of mycelia growth and $95.95 \%$ inhibition of spore germination of Curvularia lunata a pathogen of grain discoloration of rice (Fig. 1). 
Table.1 Inhibitory effect of different plant leaf extracts and panchgavya on mycelial growth of Rhizoctonia solani in vitro condition (at $10 \%$ concentration)

\begin{tabular}{|c|c|c|c|c|c|c|}
\hline \multirow[t]{2}{*}{ Plant species } & \multicolumn{2}{|c|}{ Cold water } & \multicolumn{2}{|c|}{ Hot water } & \multicolumn{2}{|c|}{ Acetone } \\
\hline & $\begin{array}{l}\text { Mycelial } \\
\text { growth } \\
\text { (mm) }\end{array}$ & $\begin{array}{l}\% \text { decrease } \\
\text { over control }\end{array}$ & $\begin{array}{l}\text { Mycelial } \\
\text { growth } \\
\text { (mm) }\end{array}$ & $\begin{array}{c}\text { \% decrease } \\
\text { over } \\
\text { control }\end{array}$ & $\begin{array}{l}\text { Mycelial } \\
\text { growth } \\
(\mathbf{m m})\end{array}$ & $\begin{array}{l}\% \text { decrease } \\
\text { over control }\end{array}$ \\
\hline $\begin{array}{c}\text { T1 - Neem (Azadirachta } \\
\text { indica) }\end{array}$ & 36.2 & 59.77 & $\mathbf{5 2 . 4 7}$ & 41.7 & 46.86 & 47.92 \\
\hline $\begin{array}{c}\text { T2 - Garlic } \\
\text { (Allium sativum) }\end{array}$ & 17.53 & 80.51 & 22.33 & 75.18 & 37.13 & 58.74 \\
\hline $\begin{array}{c}\text { T3 - Datura } \\
\text { (Datura stramonium) }\end{array}$ & 53.8 & 40.22 & 48.67 & 45.92 & 32.4 & 63.99 \\
\hline $\begin{array}{c}\text { T4 - Lemon grass } \\
\text { (Cymbopogan flexousus) }\end{array}$ & 90.0 & 0.0 & 72.07 & 19.92 & 84.87 & 5.70 \\
\hline T5- Panchgavya & 73.27 & 18.59 & 62.66 & 30.36 & 58.40 & 35.11 \\
\hline Control & 90.0 & - & 90.0 & - & 90.0 & - \\
\hline $\mathbf{S E}(\mathbf{m})+$ & 2.6312 & & 1.9808 & & 2.6464 & \\
\hline CD $(5 \%)$ & 8.1078 & & 6.1035 & & 8.1545 & \\
\hline
\end{tabular}

The extract of each plant species were prepared in cold water, hot water and Acetone by leaf tissues and solvent in $1: 1$ ratio $(\mathrm{w} / \mathrm{v}) .5$ plates in each replication

\section{Fig.1}

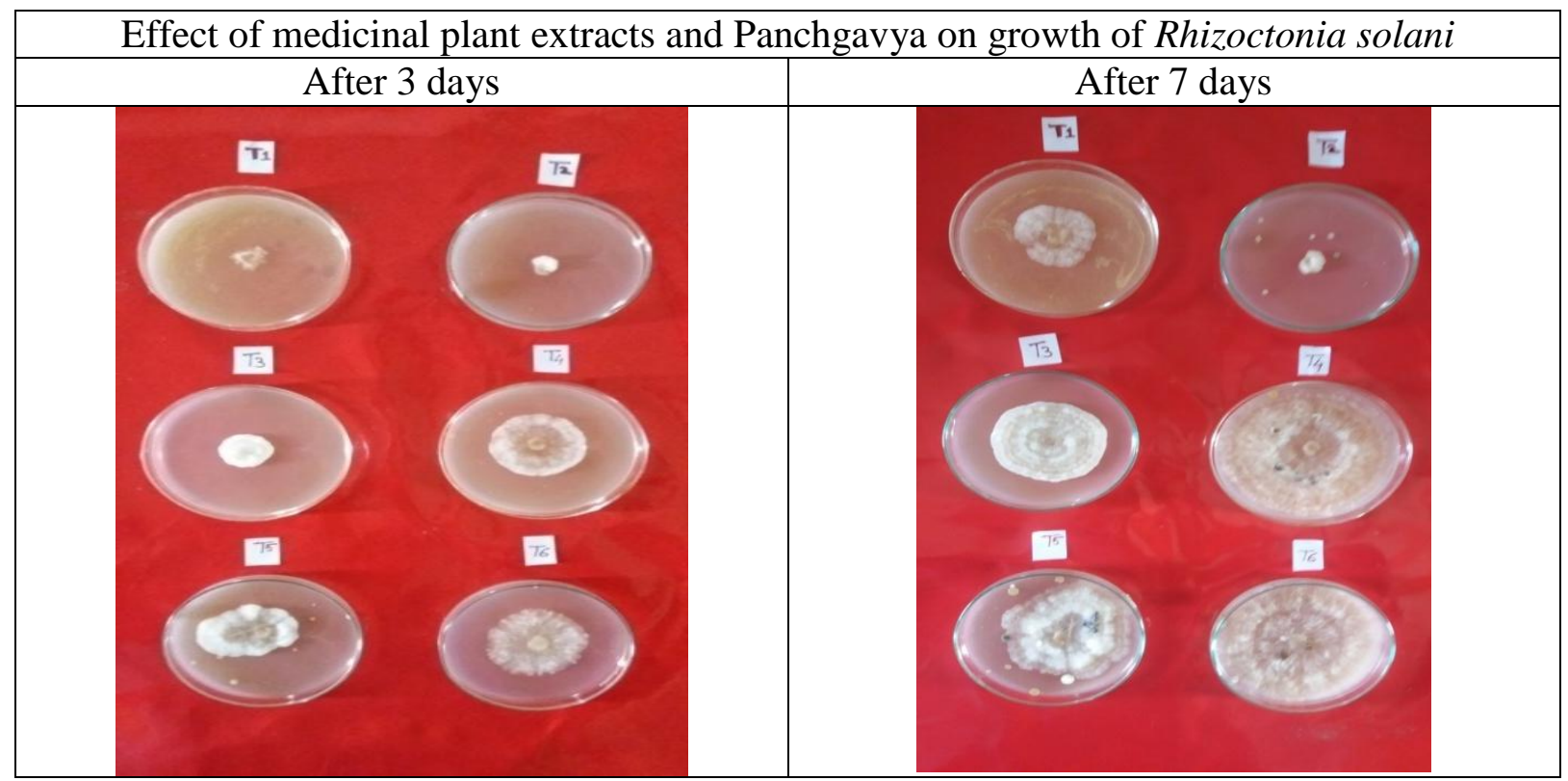

Raja and Kurucheve (1997) also observed the efficacy of Panchgavya ingredients i.e. cow urine and milk under in vitro against $R$. solani, the sheath blight pathogen and found that $20 \%$ concentration of cow urine was totally inhibited the mycelia growth and sclerotial production. 
Earlier workers reported the antifungal activity of cow urine (Basak and Lee, 2005) and dung (Ashlesha et al., 2009) against soil borne pathogens. The strong fungitoxicity of panchgavya against different fungal pathogens viz., F. oxysporum, F. solani, Rhizopus oligosporus (Joseph and Sankarganesh, 2011), $R$. solani, S. rolfsii (Sugha, 2005; Dogra, 2006), Sclerotinia sclerotiorum (Shalika, 2009), Phytophthora capsici and Colletotrichum coccodes (Sinha et al., 2010) has been studied.

The release of antimicrobial compounds may be due to the microorganisms (bacteria, fungi and actinomycetes) present in panchgavya (Swaminathan et al., 2007). Panchgavya found most effective at 10 percent concentration under in vitro conditions (Ashlesh and Paul, 2014). A definite trend in the efficacy of medicinal plant leaf extracts was not observed with respect to solvents i.e. cold water, hot water and Acetone. The variation in the efficacy might be due to presence of different antifungal compounds in different solvents. It is not necessary that all the antifungal compounds could be present in all the solvents (extracts) or the quantity may vary depending upon the kind of solvent used for extraction.

In this study, no sclerotia formation and less mycelial growth was observed. This might be due to reduction in the active mycelial growth and finally no aggregation of mycelial strands takes place for formation of sclerotia.

Efficacy of medicinal plant extracts extracted in various solvents against $R$. solani including Neem based formation was reported by various workers supports the present findings (Naidu and John, 1981; Devi et al., 1982; Tewari and Premalatha Dath, 1984; Shukla et al.,1990; Kotasthane and Lakpale, 1994; Ansari, 1995; Shivpuri et al.,1997; Dubey, 1998; Kandhari and Singh, 2000 and Reddy and Sudhakar, 2002).

\section{References}

Ansari, M. M. 1995. Control of sheath blight of rice by plant extract. Indian Phytopath. 48 (3): 268-270.

Ashlesha and Paul A.S.(2014). Antifungal Bioefficacy of Organic Inputs Against Fungal Pathogens of Bell Pepper. Paripex - Indian Journal of Research, 3(6): 4-9.

Devi, S. B., Naseema, A. and Nair, M. C. 1982. In vitro effect of lemon grass oil on the mycelial growth of Rhizoctonia solani. Indian Phytopath. 35 : 714-716.

Dubey, S. C. 1998. Evaluation of different fungal antagonists, plant extracts and oil cakes against Thanatephorus cucumeris causing banded blight of rice. J. Mycol. Pl. Pathol. 28: 266-269.

Kagale S, Marimuthu T, Thayumanavan B, Nandakumar R, Samiyappan R. Antimicrobial activity and induction of systemic resistance in rice by leaf extract of Datura metel against Rhizoctonia solani and Xanthomonas oryzae pv. Oryzae. Physiological and Molecular Plant Pathology. 2004; 65:91-100.

Kandhari, J. and Singh, R. P. 2000. Efficacy of different extracts of certain indigenous plants against sheath blight pathogen of rice. J. Mycopathol. Res. 38 (20): 125-127.

Kotasthane, A. S. and Lakpale, N. 1994. Efficacy of plant and seed extract on growth and sclerotial production of Rhizoctonia solani causing sheath blight. Adv. Pl. Sci. 2: 407-410.

Naidu, V. D. and John, V. T. 1981. In vitro inhibition of rice fungal pathogens by extracts from higher plant. Int. Rice Res. Newsl. 6 (5) :12.

Reddy, C. S. and Sudhakar, R. 2002. Efficacy of plant product and other chemical in the management of sheath blight of 
rice. Fro.in Micro. Bio...and Pl. Path. 263-267.

Shivpuri, A., Sharma O. P. and Jhamaria, S. L. 1997. Fungitoxic properties of plant extracts against pathogenic fungi. $J$. Mycol. Pl. Pathol. 27(1): 29-31.

Shukla, R. P., Singh, R. K. and Diwedi, R. S. 1990. Efficacy of fungicide against enzymes produced by rice sheath blight pathogen. Int. Rice Res. Newsl. 5: $15-20$.

Swaminathan, C., Swaminathan, V. and Vijayalakshmi, K., (2007).
Panchagavya - Boon to organic Farming, International Book, Distributing Co., Lucknow.

Tewari, S. N. and Premalatha Dath, A. 1984. Effect of leaf extract media of some plant on the growth of three fungal pathogens of rice. Indian Phytopath. 37 : 458-461.

Vincent, J. M. 1947. Distortion of fungal hypha in presence of certain inhibitors.Nature.196-596.

\section{How to cite this article:}

Toorray, N.K., P.K. Tiwari, A.S. Kotasthane and Saxena, R.R. 2019. In vitro Evaluation of ITKs (Indigenous Technical Knowledge's) Techniques viz., Application of Panchgavya and Plant Extracts against Rhizoctonia solani. Int.J.Curr.Microbiol.App.Sci. 8(11): 1819-1824. doi: https://doi.org/10.20546/ijcmas.2019.811.213 